\title{
Effect of swash climate and food availability on sandy beach macrofauna along the NW coast of the Iberian Peninsula
}

\author{
Mónica Incera ${ }^{1,2, *}$, Mariano Lastra ${ }^{1}$, Jesús López ${ }^{1}$ \\ ${ }^{1}$ Departamento de Ecología e Biología Animal, Facultade de Ciencias, Universidade de Vigo, Spain \\ ${ }^{2}$ Present address: Dipartimento di Biologià, Università, Via A. Volta 6, 56126 Pisa, Italy
}

\begin{abstract}
The swash exclusion hypothesis (SEH) is widely used in explaining the abundance and diversity of macrofauna in sandy beaches. This hypothesis predicts a reduction in richness, abundance and biomass of macrofaunal assemblages from flat slope beaches to steep slope ones due to the swash climate. Nevertheless, flat slope beaches are characterised by greater food availability than steep slope beaches; thus, food supply may also explain macrofaunal trends in exposed sandy beaches. This paper investigates the relative importance of food availability (expressed as biopolymeric carbon and chlorophyll a) and swash climate within this macrofauna impoverishment. Macrofaunal assemblages and sediment food availability were studied at 3 levels on the shore, 2 intertidal and 1 supratidal, at each of 11 sandy beaches located on the NW coast of the Iberian Peninsula. Results indicated that: (1) the beach slope had a stronger effect on richness, density and biomass of macrofaunal assemblages at the intertidal than at the supratidal level; (2) steep slope beaches presented a higher percentage of active burrower species than flat slope beaches; and (3) species richness, density and biomass of macrofauna were not related to food availability, measured as biopolymeric carbon and chlorophyll $a$ in the sediment. Overall, our results strongly support the idea that the harsh swash climate of steep slope beaches may exclude some species without active and rapid burrowing abilities, and is probably one of the mechanisms responsible for the observed decrease of macrofauna in this habitat.
\end{abstract}

KEY WORDS: Sandy beaches · Swash Exclusion Hypothesis · Biopolymeric carbon · Swash climate · Beach slope $\cdot$ NW Spain

\section{INTRODUCTION}

It is widely acknowledged that physical factors modulate the strength of biological interactions. Therefore, the interplay between abiotic and biotic factors is a topic of considerable ecological interest (Danielson 1991, Schoeman \& Richardson 2002, Badyaev 2005). In extreme environments, biological interactions are minimal and assemblages are structured by independent responses of individual species to the physical environment (Noy-Meir 1979, Hodkinson 2003). In such environments, the harsh climate imposes a high selective pressure on the organisms, induces phenotypic changes and usually non-tolerant species are excluded (Addo-Bediako et al. 2002, Badyaev 2005).

On coastal sandy shores, one of the harshest marine habitats, beach morphodynamics, that is the mutual interaction of waves and tides with the beach topography (Short 1999), have relevant consequences on intertidal macrofauna (Defeo \& McLachlan 2005 and references therein). In this context, the swash, i.e. the water movement over the beach face after a broken wave (bore) collapses on the sand (McArdle \& McLachlan 1991, 1992), changes among the different morphodynamic beach types. Flat dissipative beaches have benign swashes, since the wave energy is consumed or dissi- 
pated in the surf zone, so that long-period and lowturbulence swashes characteristically occur on these types of beaches. Conversely, on steep reflective beaches waves break directly on the beach face generating a harsh swash climate characterised by short period and turbulent swashes (McArdle \& McLachlan 1991, 1992). In general, species richness, total abundance and biomass of macrofaunal assemblages decrease along the physical gradient from benign dissipative to harsh reflective sandy beaches (Defeo \& McLachlan 2005 and references therein). The main hypothesis proposed to explain the relationship between macrofauna (meio and microfauna are probably not affected by the swash climate; Rodríguez et al. 2003) and morphodynamics on sandy beaches is known as the Swash Exclusion Hypothesis (SEH). It suggests that the harsher swash conditions of steep slope beaches determines a progressive decrease in diversity and macrofaunal abundance and could cause, in extreme situations, the complete exclusion of intertidal species from the swash zone (McLachlan et al. 1993, 1995). Thus, mortality on exposed beaches may be reduced when they are flat and dissipative (McArdle \& McLachlan 1991). Implicitly, the SEH suggests that burrowing abilities might be a factor in determining the distribution of species and community structure in beaches of different slope (Dugan et al. 2004).

However, other hypotheses can be proposed to explain the relationship between macrofauna and beach characteristics. The larger availability of organic matter and the higher retention of organic particles in flat as opposed to steep slope beaches (Talbot \& Bate 1989, Incera et al. 2003a,b) could also explain the observed macrofaunal pattern. Although these 2 hypotheses are not mutually exclusive, appropriate tests are needed to separate their relative contribution in structuring macrofaunal assemblages.

One prediction of the SEH is that intertidal species should increase in species number, abundance and biomass from steep reflective beaches to flat dissipative ones. Moreover, species showing relative independence of swash climate effects, mainly organisms living at the supratidal level that generally have 'autonomous active movement' (sensu Giménez \& Yannicelli 1997), would not show such trends (Defeo \& Gómez 2005, Defeo \& McLachlan 2005). Another prediction is that macrofaunal assemblages in steep reflective beaches should be composed mainly by active and rapid burrower species. Species with burrowing abilities may be able to successfully inhabit steep slope beaches, with their short period and highly turbulent swashes (McLachlan et al. 1995, Dugan et al. 2000). In contrast, in flat slope beaches organisms with a much wider range of behavioural and morphological adaptations, including slow burrowers, are expected.
Most of the previous studies testing the SEH in sandy beach macrofauna compared macrofaunal assemblages or populations between only 2 sandy beaches with contrasting morphodynamic conditions (Dugan et al. 2000, Defeo \& Martínez 2003, Defeo \& Cardoso 2004, Brazeiro 2005, Defeo \& Gómez 2005). Such comparisons, while interesting in describing community differences, confound the potential effects of the type of beach with any other intrinsic differences among beaches, regardless of morphodynamics. A better test of the SEH requires the use of sandy beaches as units of analysis along the reflective-dissipative continuum, avoiding pseudoreplication (Hurlbert 1984). This study examines the predictions of the SEH by comparing species richness, density and biomass of macrofaunal assemblages at 3 levels on the shore, 2 intertidal (affected by the swash climate) and 1 supratidal (not affected by the swash climate), among 11 sandy beaches located on the NW coast of the Iberian Peninsula. Different swash characteristics and different pigment and labile organic matter concentrations at those beaches enable us to evaluate the influence of physical characteristics and food resources on macrofaunal assemblages.

\section{MATERIALS AND METHODS}

Sediment sampling was carried out at 11 beaches located on the NW coast of the Iberian Peninsula (Fig. 1). Tidal conditions were meso-macrotidal, rang-

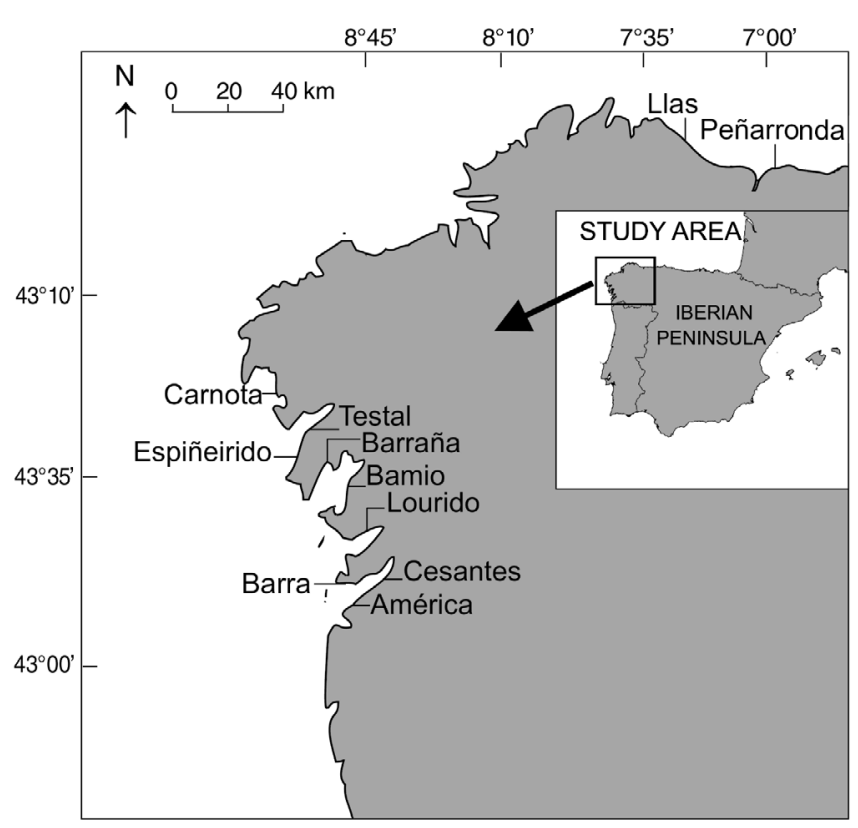

Fig. 1. Locations of the 11 sampled beaches on the NW coast of the Iberian Peninsula 
Table 1. Physical characteristics of the studied beaches. Mean grain size and sediment redox potential represent means of the 3 tidal levels

\begin{tabular}{|lccccc|}
\hline Beach & $\begin{array}{c}\text { Beach } \\
\text { length }(\mathrm{m})\end{array}$ & $\begin{array}{c}\text { Intertidal } \\
\text { width }(\mathrm{m})\end{array}$ & $\begin{array}{c}\text { 1/slope } \\
\text { Mean grain } \\
\text { size }(\mu \mathrm{m})\end{array}$ & $\begin{array}{c}\text { Sediment redox } \\
\text { potential }(\mathrm{mV})\end{array}$ \\
\hline Llas & 800 & 69 & 14 & 413.8 & 131.67 \\
Espiñeirido & 1300 & 133 & 16 & 803.6 & 223.82 \\
Barra & 1300 & 72 & 17 & 247.9 & 111.76 \\
Testal & 1800 & 70 & 20 & 853.0 & 93.32 \\
América & 2300 & 104 & 23 & 903.1 & 48.68 \\
Carnota & 7000 & 133 & 37 & 678.6 & 90.52 \\
Peñarronda & 600 & 218 & 40 & 259.1 & 87.64 \\
Bamio & 70 & 278 & 69 & 1138.3 & 36.89 \\
Lourido & 700 & 272 & 77 & 1138.7 & 43.91 \\
Cesantes & 2400 & 210 & 80 & 962.6 & -40.37 \\
Barraña & 2100 & 352 & 88 & 1325.0 & -138.79 \\
\hline
\end{tabular}

ing from 3.5 to $4 \mathrm{~m}$ in the spring tides. The environmental characteristics of these beaches are shown in Table 1. Each beach was sampled once between July and September 1997, with the exception of Barra that was sampled in August 1998, during spring tides. Samples were collected during low tides at 3 levels on the shore (hereafter beach levels), 2 intertidal (low and medium) affected by the swash climate, and 1 supratidal not affected by the swash climate. By sampling these 3 levels we could study specific predictions of the $\mathrm{SEH}$ on the 3 most representative environments of the beach: the low swash environment, having an assemblage of typically subtidal and intertidal species; the truly intertidal part of the beach; and the supratidal zone, where only resistant and semiterrestrial species are present. The beach division was based on the scheme proposed by Salvat (Salvat 1964). Low beach level was located in the medium swash point during low tide. Medium beach level was determined as the tidal position at the intermediate time between high and low tides and the supratidal beach level was located at the drift line. Macrofaunal samples were collected with a metallic cylinder of $188.69 \mathrm{~cm}^{2}$ crosssectional and $15 \mathrm{~cm}$ long. Intertidal macrofauna is mainly found in the first $15 \mathrm{~cm}$ of sediment (about 95\% of the individuals; Palacio et al. 2001). Nine consecutive samples ( 0.5 to $2 \mathrm{~m}$ apart) were collected at random at each beach level. Samples were sieved through $1 \mathrm{~mm}$ mesh and preserved in $4 \%$ formalin-sea water solution. All macroinvertebrates were sorted and determined to the lowest taxonomic level possible (usually species). Biomass (ash-free dry weight) was obtained by loss of mass on ignition $\left(500^{\circ} \mathrm{C}\right.$ for $\left.6 \mathrm{~h}\right)$ of oven-dried samples $\left(80^{\circ} \mathrm{C}\right.$ until constant weight). Density and biomass of macrofauna by $\mathrm{m}^{2}$ were calculated as the mean value of the 9 samples collected at each beach level. At each beach level the sediment redox potential was determined in situ at $5 \mathrm{~cm}$ intervals down to $25 \mathrm{~cm}$ sediment depth using an Ehelectrode (Metrohm 740) connected to an $\mathrm{mV}$ meter. The beach slope was determined by Emery's (1961) profiling technique from the entire beach, i.e. from the base of the dunes to the lower limit of the swash zone. Thus, the beach slope represents the average inclination of each beach. Beach slope is closely related to swash climate, wave energy and grain size (Emery \& Gale 1951, McArdle \& McLachlan 1991) and could be considered a good proxy of the characteristics of the swash climate. In our study the slope was highly correlated with other physical characteristics of the beaches such as grain size $(r=0.71, p=0.014)$ and redox potential $(\mathrm{r}=-0.95, \mathrm{p}<0.001)$. Typically, beaches of low slopes have wide and benign swash zones while beaches with steep slopes have narrow and harsh swash zones. Although composite indices of beach state have been useful in some cases to classify sandy beaches into morphodynamic types, they were not taken into account in this study due to the high variability of wave height and period (used in its calculation) in the studied beaches.

Sediment samples for biochemical and chlorophyll $a$ analyses were collected in triplicate at each beach level (low, medium and supratidal) with a metallic cylinder of $188.69 \mathrm{~cm}^{2}$ cross-sectional and $15 \mathrm{~cm}$ long. Samples were mixed and homogenized before collecting subsamples of 30 and $6 \mathrm{~cm}^{3}$ for biochemical and pigments analyses, respectively. All biochemical analyses were conducted on sediment samples previously oven dried at $60^{\circ} \mathrm{C}$ until constant weight and finely powdered with a pestle (Pulverisette 2, Fritsch). Seawater samples $\left(3 \mathrm{dm}^{3}\right)$ for biochemical analyses were filtered from the swash zone in triplicate at low, medium and supratidal level with GF/F glass microfibre filters. Total lipids (Zöllner \& Kirsch 1962), carbohydrates (Dubois et al. 1956) and proteins (Lowry \& Rosebrough 1951 as modified by Markwell et al. 1978) were analysed. A detailed description of the biochemical analyses is reported in Cividanes et al. (2002) and Incera et al. (2003a). Carbohydrate, protein and lipid concentrations were converted to carbon equivalents assuming a conversion factor of $0.45,0.5$ and 0.7 , respectively (Fabiano et al. 1995). The sum of lipid, protein and carbohydrate carbon was referred to as the biopolymeric carbon (BPC sensu Mayer 1989, Fabiano et al. 1995) and utilised to estimate the fraction potentially available for benthic consumers. Analyses of sediment chlorophyll a were carried out according to Lorenzen (1967). Pigments were extracted with 
Table 2. List of macrofaunal species recorded at the studied beaches. Active burrower species and non-active burrower species are indicated as + and -, respectively

\begin{tabular}{|c|c|c|c|}
\hline Taxa & & Taxa & \\
\hline Polychaeta & & Crustacea & \\
\hline Anaitides mucosa & + & Decapoda & \\
\hline Arenicola marina & - & Carcinus maenas & + \\
\hline Megalomma vesiculosum & - & Crangon crangon & + \\
\hline Capitellidae indet. & - & Portunus latipes & + \\
\hline Dispio sp. & - & Upogebia pusilla & + \\
\hline Eteone longa & + & Amphipoda & \\
\hline Eteone picta & + & Aora typica & - \\
\hline Glycera tridactyla & + & Bathyporeia pelagica & + \\
\hline Goniada sp. & - & Bathyporeia sp. & + \\
\hline Heteromastus filiformis & - & Corophium insidiosum & - \\
\hline Lumbrineris impatiens & + & Dexamine spinosa & - \\
\hline Lumbrineris sp. & + & Erichthonious brasiliensis & - \\
\hline Lumbrineris tetraura & + & Gammarus sp. & - \\
\hline Nephtys cf. саесa & + & Haustorius arenarius & + \\
\hline Nephtys cirrosa & + & Malacoceros vulgaris & - \\
\hline Nephtys hombergii & + & Melita palmata & - \\
\hline Nephtys sp. & + & Microdeutopus gryllotalpa & - \\
\hline Nereis diversicolor & - & Microdeutopus sp. & - \\
\hline Notomastus latericeus & - & Microphthalmus sp. & - \\
\hline Ophelia bicornis & - & Microprotopus maculatus & - \\
\hline Phyllodocidae indet. & + & Pontocrates arenarius & + \\
\hline Polydora ciliata & - & Talorchestia brito & - \\
\hline Protodriloides chaetifer & - & Talorchestia deshayesii & - \\
\hline Protodrilus indet. & - & Talitrus saltator & - \\
\hline Pseudopolydora sp. & - & Isopoda & \\
\hline Pygospio elegans & - & Cyathura carinata & + \\
\hline Saccocirrus sp. & - & Eurydice affinis & + \\
\hline Scolelepis squamata & + & Sphaeroma rugicauda & + \\
\hline Scoloplos armiger & - & Sphaeroma serratum & + \\
\hline Spiophanes bombyx & - & Cumacea & \\
\hline Mollusca & & Cumopsis fagei & + \\
\hline Cerastoderma edule & - & Cumopsis longipes & + \\
\hline Donax trunculus & + & Cumopsis sp. & + \\
\hline Hydrobia ulvae & - & Mysidacea & \\
\hline Parvicardium exiguum & - & Eocuma dollfusi & + \\
\hline Scrobicularia plana & + & Gastrosaccus sanctus & + \\
\hline Tapes decussatus & - & Hemimysis lamornae & + \\
\hline Tellina tenuis & + & Iphinoe serrata & + \\
\hline \multirow{3}{*}{ Venerupis pullastra } & + & Paramysis nouveli & + \\
\hline & & Schistomysis cf. parkeri & + \\
\hline & & Schistomysis kervillei & + \\
\hline
\end{tabular}

in the literature for any of the macrofaunal species found in this study, therefore species were classified as 'active burrowers' or 'non-active burrowers' on the basis of information from taxonomic studies. Thus, among all the species in our data set, 4 families of amphipods (Oedicerotidae, Phoxocephalidae, Haustoriidae and Argissidae) were classified as active burrowers due to their posterior pereopods modified for digging (Lincoln 1979). All species of cumaceans, mysidaceans, isopods and decapods are characterised by high swimming and burrowing ability (Jones 1976, Alheit \& Naylor 1976). The burrowing ability of bivalves was predicted from the shape of foot and shell as proposed by Trueman et al. (1966) and Stanley (1970). These authors suggest that bivalves with a well-developed foot, cylindrical 3-dimensional shellshape, thin shell and weak shell ornamentation are efficient burrowers. Polychaeta living inside tubes or burrows within the substrate were considered unable to withstand the harsh swash conditions because these structures would be badly damaged in these conditions (McLachlan 1980). In contrast, a conic head with reduced or absent structures, such as antennae, palps or tentacular cirri, were considered as advantageous attributes for burrowing (Fauvel 1969, Trevor 1976).

Statistical analyses. Data were analysed using a general linear mixed model, to accommodate a combination of fixed and random effects (von Ende 1993). The mixed model approach

$90 \%$ acetone solution for $1 \mathrm{~h}$ at $11^{\circ} \mathrm{C}$ in darkness. The extract was centrifuged at $4000 \mathrm{rpm}$ for $10 \mathrm{~min}$ and the light absorbance was measured with a UV/Vis spectrophotometer (Unicam).

In order to test the predictions of the $\mathrm{SEH}$, we assess whether species with active and rapid burrowing abilities (thereafter active burrower species), which allow them to withstand the harsh physical conditions of the swash environment, were more frequent on steep beaches than on flat ones (Table 2). The behaviour of each species would be very useful in order to classify the organisms into active and nonactive burrowers. This information was not available extends the familiar general linear model by allowing for both correlation and heterogeneous variances, but still assumes approximate normality (Littell et al. 1996). Beaches were modelled as random factors to avoid problems of pseudoreplication. Beach level (low, medium and supratidal) was included in the model as a fixed factor within subjects (beaches) and the reciprocal of slope as fixed between-subject covariate. General linear mixed models were used to assess the effects of beach level, the reciprocal of slope and their interactions on macrofauna descriptors, on active burrower species and on sediment food availability. Further, we tested whether the addition of a quadratic 
Table 3. Mixed linear model analysis of the effects of beach level (low, medium and supratidal) and 1/slope, on the concentrations of chlorophyll $a(\mathrm{chl} a)$ in sediments $\left(\mu \mathrm{g} \mathrm{g}^{-1}\right.$ dry weight) and of biopolymeric carbon (BPC) in sediments $\left(\mu \mathrm{g} \mathrm{g}^{-1}\right.$ dry weight) and in water column $\left(\mu \mathrm{g} \mathrm{l}^{-1}\right)$

\begin{tabular}{|c|c|c|c|c|c|c|c|}
\hline \multirow[t]{2}{*}{$\begin{array}{l}\text { Source of } \\
\text { variation }\end{array}$} & \multicolumn{3}{|c|}{ Chl a } & \multicolumn{2}{|c|}{$\begin{array}{c}\text { BPC } \\
\text { (Sediment) }\end{array}$} & \multicolumn{2}{|c|}{$\begin{array}{c}\text { BPC } \\
\text { (Water column) }\end{array}$} \\
\hline & df & $F$ & $\mathrm{p}$ & F & $\mathrm{p}$ & $F$ & $\mathrm{p}$ \\
\hline Beach level & $2 / 18$ & 2.01 & 0.16 & 0.85 & 0.44 & 2.40 & 0.12 \\
\hline 1/Slope & $1 / 9$ & 0.56 & 0.47 & 16.68 & 0.003 & 4.40 & 0.065 \\
\hline $\begin{array}{c}\text { Beach level } \\
\times 1 / \text { Slope }\end{array}$ & $2 / 18$ & 1.08 & 0.36 & 1.52 & 0.24 & 7.35 & 0.005 \\
\hline
\end{tabular}

term significantly improved the linear model, but in all cases this term was not significant. When necessary, transformations were used to achieve the assumptions of homogeneity of variances and normality (Sokal \& Rohlf 1995).

\section{RESULTS}

\section{Food availability}

Food availability in sediments, measured as biopolymeric carbon concentration, was significantly related to beach slope (Table 3), with steeper beaches showing lower concentrations than flatter ones (Fig. 2a). Although the lowest concentration of biopolymeric carbon tended to occur at the supratidal level, the effect of beach level and the interaction between beach level and slope were not significant (Table 3). There was a significant interaction between beach slope and tidal level on biopolymeric carbon concentration in water column (Table 3). Thus, only the low tidal level showed a relationship between biopolymeric carbon concentration in water column and beach slope (Fig. 2b). The concentration of chlorophyll a was not significantly influenced by the slope, the beach level or the interaction between beach level and slope (Fig. 2c, Table 3). However, 2 different groups of beaches were graphically evident: steep beaches with high concentrations of chlorophyll $a$, and flat beaches with lower concentrations of this pigment (Fig. 2c).

\section{Sandy beach macrofauna}

Density, species number and biomass were closely related to beach slope, showing lower values in steep than in flat slope beaches (Fig. 3, Table 4). Nevertheless, this relationship was affected by the beach level as it is shown by the significant interaction between slope and beach level (Table 4). Thus, the relationship between macrofaunal descriptors and intertidal slope differs among beach levels, being higher on medium and low levels than on the supratidal (Fig. 3). Density, species number and biomass were not significantly related to biopolymeric carbon (sediment and water column) and chlorophyll a concentrations, although the relationship between chlorophyll $a$ and total biomass was close to significance (Table 4).
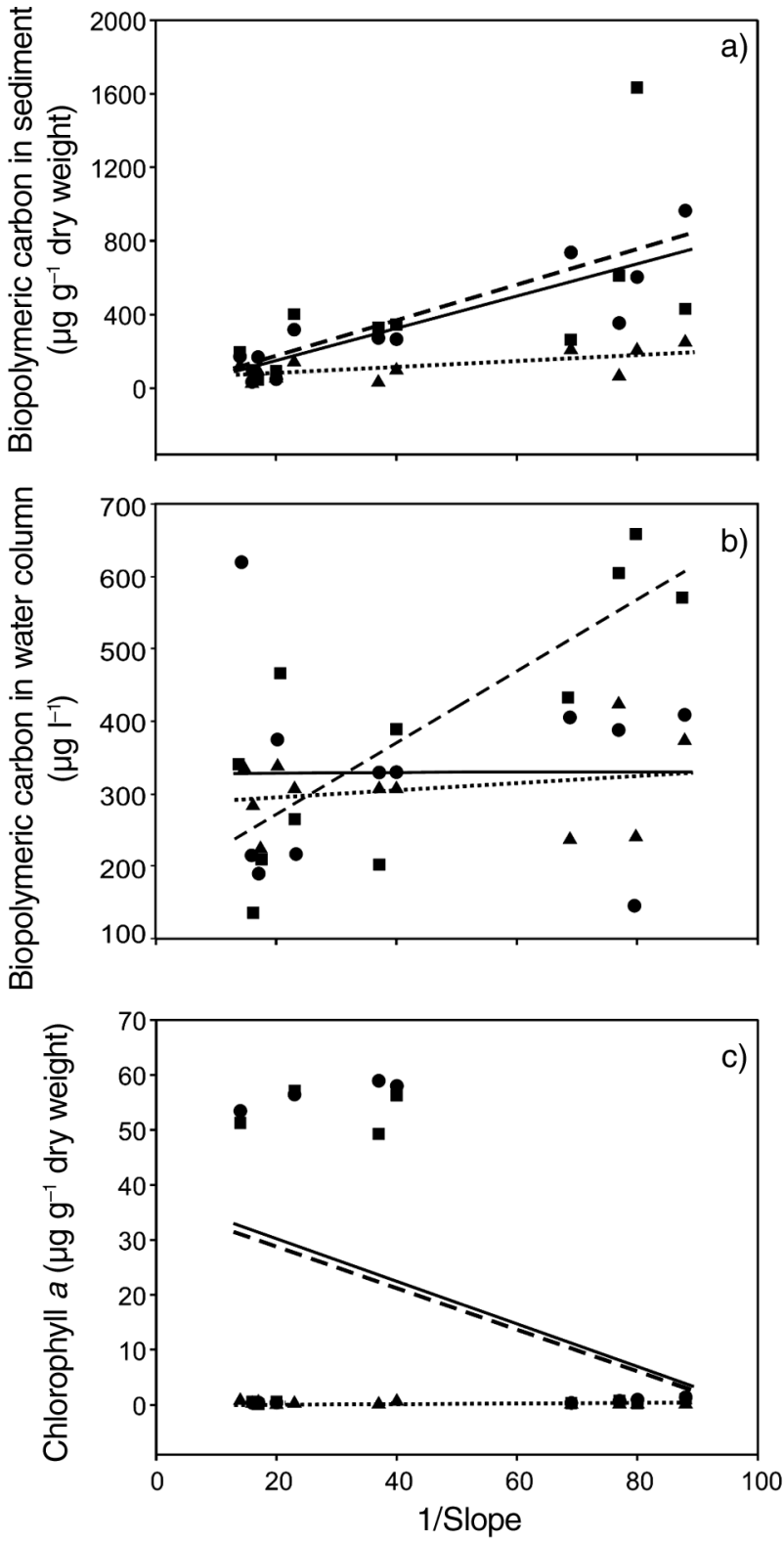

Fig. 2. Relationship between 1/slope and (a) biopolymeric carbon in sediments, (b) biopolymeric carbon in water column and (c) chlorophyll a. $(\boldsymbol{\Lambda}, \cdots \cdots)$ Supratidal level; $(\bullet,-)$ medium level; $(\boldsymbol{\square},---)$ ) low level. Lines indicate estimated trends from general mixed model analysis 
Table 4. Mixed linear model analysis of the effects of beach level (low, medium and supratidal), 1/slope, chlorophyll a (chl $a_{i} \mu \mathrm{g} \mathrm{g}^{-1}$ dry weight) and biopolymeric carbon (BPC) in sediment and water column $\left(\mu \mathrm{g} \mathrm{g}{ }^{-1}\right.$ dry weight and $\mu \mathrm{g} \mathrm{l}^{-1}$, respectively) on density (ind. $\mathrm{m}^{-2}$ ), number of species and biomass $\left(\mathrm{g} \mathrm{m}^{-2}\right)$ of macrofauna

\begin{tabular}{|c|c|c|c|c|c|c|c|}
\hline \multirow{2}{*}{$\begin{array}{l}\text { Source of } \\
\text { variation }\end{array}$} & \multicolumn{3}{|c|}{ Density } & \multicolumn{2}{|c|}{ No. of species } & \multicolumn{2}{|c|}{ Biomass } \\
\hline & df & $F$ & $\mathrm{p}$ & $F$ & $\mathrm{p}$ & $F$ & $\mathrm{p}$ \\
\hline Beach level & $2 / 12$ & 0.29 & 0.74 & 1.27 & 0.31 & 1.2 & 0.31 \\
\hline 1/Slope & $1 / 12$ & $23.73<$ & $<0.001$ & 14.76 & 0.002 & 7.71 & 0.010 \\
\hline $\begin{array}{l}\text { Beach level } \\
\times 1 / \text { Slope }\end{array}$ & $2 / 12$ & $11.58<$ & $<0.001$ & 10.08 & 0.002 & 11.57 & $<0.001$ \\
\hline $\mathrm{Chl} \mathrm{a}$ & $1 / 23$ & 1.38 & 0.25 & 0.03 & 0.85 & 3.38 & 0.08 \\
\hline $\begin{array}{l}\text { BPC } \\
\text { (sediment) }\end{array}$ & $1 / 23$ & 0.28 & 0.59 & 2.34 & 0.14 & 0.72 & 0.40 \\
\hline $\begin{array}{l}\text { BPC (water } \\
\text { column) }\end{array}$ & $1 / 23$ & 1.88 & 0.18 & 0.05 & 0.94 & 2.32 & 0.14 \\
\hline
\end{tabular}

\section{Active burrower species}

Abundance and species number of active burrower species (expressed as percentages), were significantly related to average beach slope (Table 5). Steep slope beaches, i.e. those with harsh swash conditions, showed a higher proportion of active burrower organisms than flat slope beaches (Fig. 4). In addition, the proportional abundance of active burrowers was higher at medium and low levels than at the supratidal level (Fig. 4, Table 5). Although the proportional abundance and richness of active burrowers tended to be higher at low and medium levels (Fig. 4), the interaction between the beach slope and the tidal level was not significant (Table 5).

\section{DISCUSSION}

The beach slope, a swash climate proxy, had relevant consequences on the macrofaunal assemblages and on the biopolymeric carbon present in sediments. Diversity, density and biomass of macrofauna and biopolymeric carbon concentrations were smaller at steep slope beaches (those with harsh swash climate) than at flat slope beaches (those with benign swash climate). The macrofaunal results, obtained in mesomacrotidal conditions, agree with previous studies (see Defeo \& McLachlan 2005 and references therein) obtained in microtidal conditions, highlighting the generality of this relationship in different tidal ranges. In order to test the relative importance of swash climate and food availability in structuring macrofaunal assemblages, this study evaluated 3 lines of evidence specific to the swash exclusion and the food availability hypotheses: (1) the interaction between the beach level and intertidal slope on macrofaunal descriptors, as predicted by the SEH (McLachlan et al. 1993, 1995) (2) the effect of intertidal slope in active burrower species, as predicted by the SEH (McLachlan et al. 1993, Defeo \& McLachlan 2005) and (3) the effect of food availability in sediments and water column on macrofaunal assemblages (McLachlan 1990).

The intertidal slope, indicative of the swash climate (Defeo \& McLachlan 2005, McLachlan \& Dorvlo 2005), had a differential effect on macrofaunal assemblages according to the beach level. Within beaches, there
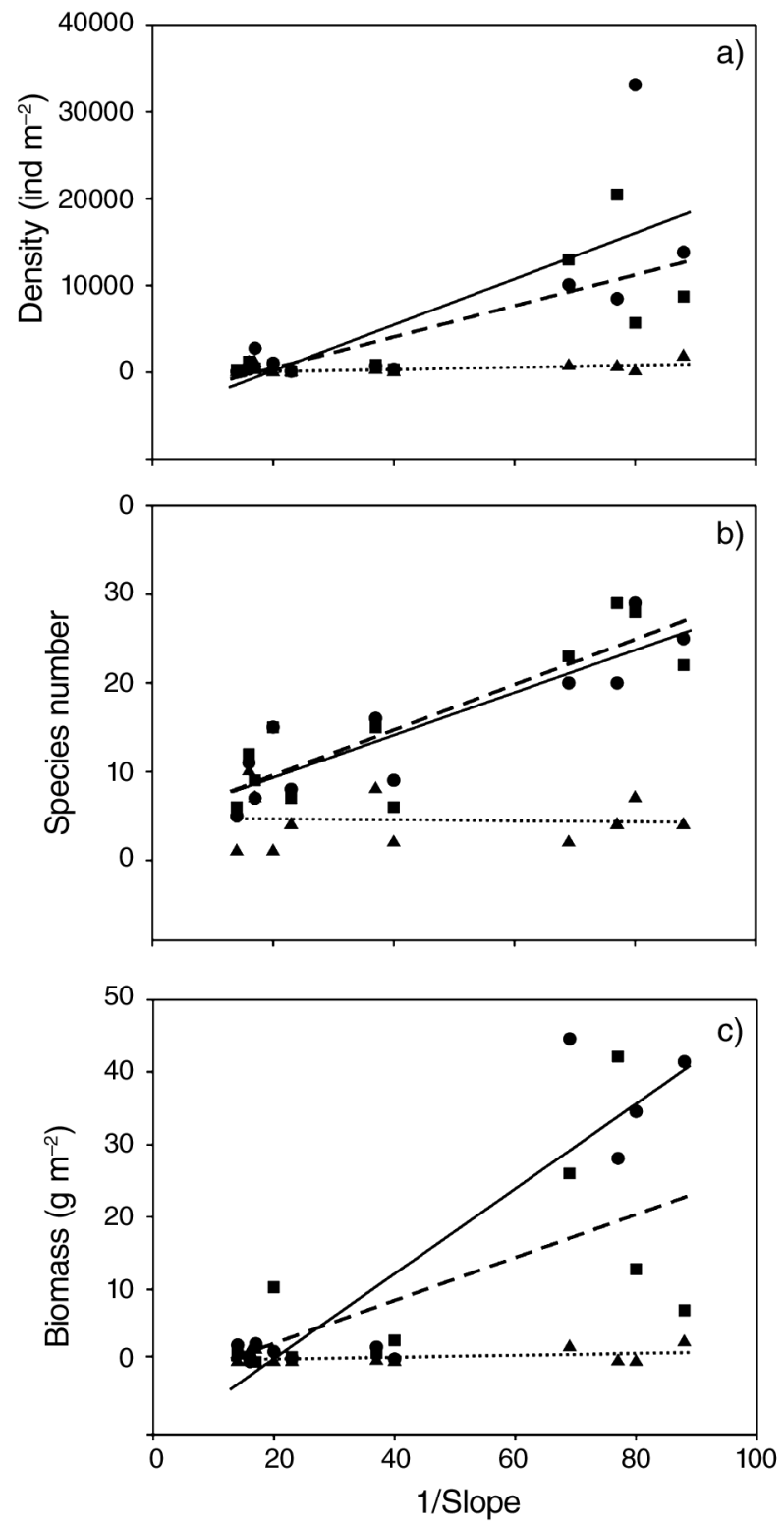

Fig. 3. Relationship between 1/slope and (a) density, (b) number of species and (c) biomass of macrofauna. $(\boldsymbol{\Lambda}, \cdots \cdots)$ Supratidal level; $(\bullet,-)$ medium level; $(\mathbf{\square},---)$ low level. Lines indicate estimated trends from general mixed model analysis 
Table 5. Mixed linear model analysis of the effects of beach level (low, medium and supratidal) and 1/slope on abundance and number of active burrower species (expressed as percentages)

\begin{tabular}{|c|c|c|c|c|c|}
\hline \multirow[t]{2}{*}{$\begin{array}{l}\text { Source of } \\
\text { variation }\end{array}$} & \multicolumn{3}{|c|}{$\begin{array}{l}\text { Abundance of active } \\
\text { burrower species (\%) }\end{array}$} & \multicolumn{2}{|c|}{$\begin{array}{c}\text { Number of active } \\
\text { burrower species (\%) }\end{array}$} \\
\hline & df & $F$ & $\mathrm{p}$ & $F$ & $\mathrm{p}$ \\
\hline Beach level & $2 / 18$ & 6.42 & 0.049 & 3.51 & 0.18 \\
\hline 1/Slope & $1 / 9$ & 17.70 & 0.001 & 12.19 & 0.003 \\
\hline $\begin{array}{l}\text { Beach level } \\
\times 1 / \text { Slope }\end{array}$ & $2 / 18$ & 2.51 & 0.35 & 0.81 & 0.79 \\
\hline
\end{tabular}

were strong relationships between the slope and the macrofaunal descriptors at medium and low intertidal levels but these relationships were not evident at the supratidal level. These results support the SEH, which predicted the exclusion of organisms at low and medium beach levels due to the swash climate, but not at supratidal level, where the action of swash is negligible (Hughes \& Turner 1999). Moreover, it was proposed that supralittoral organisms are relatively independent of the swash regime, resulting in variable responses to changes of the beach type (Defeo \& Gómez 2005).

The second line of evidence supporting the SEH came from the fact that steep slope beaches with harsh swashes showed higher percentages of density and diversity of active burrower species than flat slope beaches with benign swashes. Moreover, there was a tendency for the proportion of active burrower species to be higher at the intertidal, where the swash is present, than at the supratidal level, although the interaction was not significant. These results strongly support the key specific prediction of the $\mathrm{SEH}$, that is, the exclusion of less active burrower species in steep slope beaches due to the extreme swash conditions present in these beaches. It is worth noting that our study was focused on a specific mechanism suited to avoid the harsh swash climate of steep slope beaches (burrowing abilities), but other mechanisms could be possible. It has been proposed, for instance, that organisms could live deep in the sediment to cope with harsh hydrodynamic conditions (Degraer et al. 2003).

Previous studies on the relationship between beach slope and patterns of occurrence of species in the swash zone showed contrasting results (Gómez \& Defeo 1999, Defeo et al. 2001, Cardoso et al. 2003), ranging from lack of relationships between beach slope and species abundance to higher abundances in the steepest beaches (Dugan \& Hubbard 1996, Gómez \& Defeo 1999, Defeo et al. 2001, Defeo \& Gómez 2005). These studies suggested that the SEH fails to explain the population patterns of these species. However, the
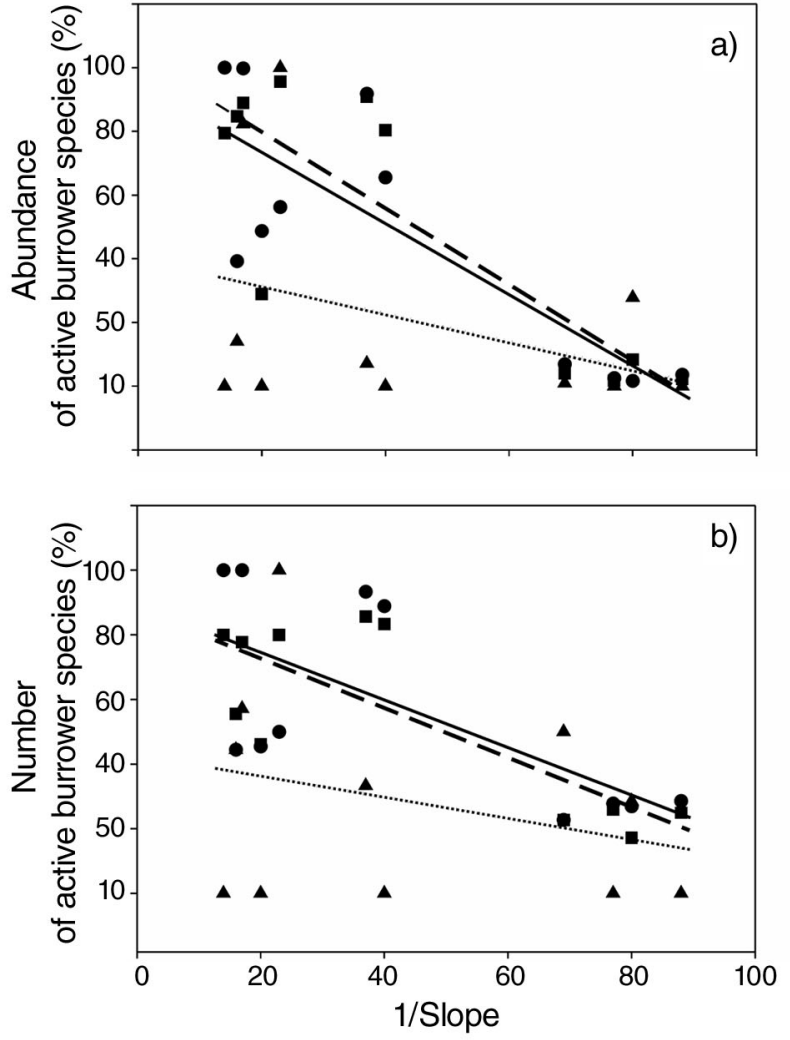

Fig. 4. Relationship between 1/slope and percentage of (a) abundance and (b) number of active burrower species $(\boldsymbol{\Lambda}, \cdots \cdots)$ Supratidal level; $(\boldsymbol{\bullet},-)$ medium level; $(\mathbf{\square},----)$ low level. Lines indicate estimated trends from general mixed model analysis

strict prediction of the SEH is that species that are not tolerant to the hydrodynamic stress would be excluded from the swash zone of steep reflective beaches, whilst species able to withstand the harsh swashes would remain (McArdle \& McLachlan 1992, McLachlan et al. 1993, Brazeiro 2001). Most of the cited studies were conducted on active burrowers or species living outside the swash zone where physical dislodgement by such factors should not be expected. Thus, we suggest that positive relationships between steep beaches and abundances of a single species should not be used to reject the $\mathrm{SEH}$, especially when examining active burrower species or species living outside the swash zone (supralittoral organisms).

Finally, we investigated the influence of sediment food availability on macrofaunal descriptors. The biopolymeric carbon was considered a measure of the organic matter fraction with the potential to be more readily available to consumers (Mayer 1989, Fabiano et al. 1995), while the sedimentary pigments were extensively utilised as tracers of the input of primary organic matter (Pfannkuche 1993, Boon et al. 1998). Although slope had a clear effect on the biopolymeric 
carbon in sediments and preliminary findings suggested that the influence of slope was stronger at medium and low levels on the beach (Incera et al. 2003a), we did not find a significant interaction between the beach slope and the tidal level. Slope, in contrast, had no effect on the concentration of pigments in sediments, suggesting that pigments did not contribute to the observed patterns of assemblages according to beach morphodynamics. We did not find any relationship between macrofaunal descriptors and food availability in the sediments and in the water column. This outcome could be due, at least in part, to the snapshot sampling design utilized and we acknowledge that our results could change when considering longer temporal scales. However, on present evidence, the observed patterns of macrofauna seem to be better explained by the swash beach characteristics than by the food availability.

In summary, our results supported the SEH predictions; species richness, density and biomass of macrofauna were lower in beaches with strong hydrodynamic conditions, but these relationships were stronger at the intertidal than at supratidal level. In addition, number and abundance of active burrower species were higher on beaches with strong hydrodynamics conditions, while macrofaunal patterns were not related to food resources. However, future studies discerning by guilds and sources of food are needed to determine whether food availability governs macrofaunal assemblages on sandy beaches. This study suggests that harsh swash conditions may impose a strong selective pressure resulting in the exclusion of slow burrower species and in the reduction of diversity and abundance of intertidal macrofaunal assemblages observed on steep slope beaches.

Acknowledgements. The authors thank 'Equipo de Bentos' from the Departamento de Ecoloxía e Bioloxía Animal of the Universidade de Vigo, for their invaluable assistance during sampling. We are particularly grateful to A. Velando, L. Benedetti-Cecchi and F. Bulleri for constructive criticisms that greatly helped us to improve the manuscript. We also thank O. Defeo and 3 anonymous reviewers who significantly improved the manuscript and I. Bertocci for his help with the English. This research was supported by the Xunta de Galicia (PGIDIT02RMA30101PR) and the Universidade de Vigo (64502C130).

\section{LITERATURE CITED}

Addo-Bediako A, Chown SL, Gaston KJ (2002) Metabolic cold adaptation in insects: a large-scale perspective. Funct Ecol 16:332-338

Alheit J, Naylor E (1976) Behavioural basis of intertidal zonation in Eurydice pulchra Leach. J Exp Mar Biol Ecol 23: 135-144

Badyaev AV (2005) Stress-induced variation in evolution: from behavioural plasticity to genetic assimilation. Proc R Soc B 272:877-886

Boon AR, Duineveld GCA, Berghuis EM, van der Weel JA (1998) Relationships between benthic activity and the annual phytopigment cycle in near-bottom water and sediments in the Southern North Sea. Estuar Coast Shelf Sci 46:1-13

Brazeiro A (2001) Relationship between species richness and morphodynamics in sandy beaches: what are the underlying factors? Mar Ecol Prog Ser 224:35-44

Brazeiro A (2005) Geomorphology induces life history changes in invertebrates of sandy beaches: the case of the mole crab Emerita brasiliensis in Chile. J Mar Biol Assoc UK 85:113-120

Cardoso RS, Veloso VG, Caetano HS (2003) Life history of Emerita brasiliensis (Decapoda: Hippidae) on two beaches with different morphodynamic characteristics. J Coastal Res 35 (Special Issue):392-401

Cividanes S, Incera M, López J (2002) Temporal variability in the biochemical composition of sedimentary organic matter in an intertidal flat of the Galician coast (NW Spain). Oceanol Acta 25:1-12

Danielson BJ (1991) Communities in a landscape: the influence of habitat heterogeneity on the interactions between species. Am Nat 137:1105-1120

Defeo O, Cardoso RS (2004) Latitudinal patterns in abundance and life-history traits of the mole crab Emerita brasiliensis on South American sandy beaches. Divers Distrib 10:89-98

Defeo O, Gómez J (2005) Morphodynamics and habitat safety in sandy beaches: life-history adaptations in a supralittoral amphipod. Mar Ecol Prog Ser 293:143-153

Defeo O, Martinez G (2003) The habitat harshness hypothesis revisited: life history of the isopod Excirolana braziliensis in sandy beaches with contrasting morphodynamics. J Mar Biol Assoc UK 83:331-340

Defeo O, McLachlan A (2005) Patterns, processes and regulatory mechanisms in sandy beach macrofauna: a multiscale analysis. Mar Ecol Prog Ser 295:1-20

Defeo O, Gómez J, Lercari D (2001) Testing the swash exclusion hypothesis in sandy beach populations: the mole crab Emerita brasiliensis in Uruguay. Mar Ecol Prog Ser 212: 159-170

Degraer S, Volckaert A, Vincx M (2003) Macrobenthic zonation patterns along a morphodynamical continuum of macro-tidal, low tide bar/rip and ultra-dissipative beaches. Estuar Coast Shelf Sci 56:459-468

Dubois M, Gilles KA, Hamilton SK, Rebers PA (1956) Colorimetric method for determination of sugars and related substances. Anal Chem 28:350-356

Dugan JE, Hubbard DM (1996) Local variation in populations of the sand crab Emerita analoga (Stimpson) on sandy beaches in southern California. Rev Chil Hist Nat 69: 579-588

Dugan JE, Hubbard DM, Lastra M (2000) Burrowing abilities and swash behaviour of three crabs, Emerita analoga Stimpson, Blepharipoda occidentalis Randall, and Lepidopa californica Efford (Anomura Hippoidea). J Exp Mar Biol Ecol 255:229-245

Dugan JE, Jaramillo E, Hubbard DM, Contreras H, Duarte C (2004) Competitive interactions in macroinfaunal animals of exposed sandy beaches. Oecologia 139:630-640

Emery KO (1961) A simple method of measuring beach profiles. Limnol Oceanogr 6:90-93

Emery KO, Gale JF (1951) Swash and swash marks. Trans Am Geophys Union 32:31-36

Ende CN von (1993) Repeated-measures analysis: growth and 
other time-dependent measures. In: Scheiner SM, Gurevitch J (eds) Design and analysis of ecological experiments. Chapman \& Hall, New York, p 113-137

Fabiano M, Danovaro R, Fraschetti S (1995) A three-year time series of elemental and biochemical composition of organic matter in subtidal sandy sediments of the Ligurian Sea (NW Mediterranean). Cont Shelf Res 15:1453-1469

Fauvel P (1969) Faune de France: polychètes sédentaries, polychètes errantes. Libraire de la Faculte des Sciences. Kraus reprint. Nendeln

Giménez L, Yannicelli B (1997) Variability of zonation patterns in temperate microtidal Uruguayan beaches with different morphodynamic types. Mar Ecol Prog Ser 160: 187-207

Gómez J, Defeo O (1999) Life history of the sandhopper Pseudorchestoidea brasiliensis (Amphipoda) in sandy beaches with contrasting morphodynamics. Mar Ecol Prog Ser 182:209-220

Hodkinson ID (2003) Metabolic cold adaptation in arthropods: a smaller-scale perspective. Funct Ecol 17:562-572

Hughes MG, Turner IL (1999) The beachface. In: Short AD (ed) Handbook of beach and shoreface morphodynamics. John Wiley \& Sons, New York, p 119-144

Hurlbert SH (1984) Pseudoreplication and the design of ecological field experiments. Ecol Monogr 54:187-211

Incera M, Cividanes SP, López J, Costas R (2003a) Role of hydrodynamic conditions on quantity and biochemical composition of sediment organic matter in sandy intertidal sediments (NW Atlantic coast, Iberian Peninsula). Hydrobiologia 497:39-51

Incera M, Cividanes SP, Lastra M, López J (2003b) Temporal and spatial variability of sedimentary organic matter in sandy beaches on the Northwest coast of the Iberian Peninsula. Estuar Coast Shelf Sci 58:55-61

Jones NS (1976) British cumaceans. The Linnean Society of London. Academic Press, London

Lincoln, RJ (1979) British marine amphipoda: Gammaridea. British Museum (Natural History), London

Littell RC, Milliken GA, Stroup WW, Wolnger RD (1996) SAS System for Mixed Models. SAS Institute, Cary, NC

Lorenzen C (1967) Determination of chlorophyll and pheopigments: spectrophotometric equations. Limnol Oceanogr 12: 343-346

Lowry OH, Rosebrough NJ (1951) Protein measurement with the folin phenol reagent. J Biol Chem 193:265-275

Markwell MAK, Hass SM, Bieber LM, Tolbert ME (1978) A modification of the Lowry procedure to simplify protein determination in membrane and lipoprotein samples. Ann Biochem 87:206-210

Mayer LM (1989) The nature and determination of non-living sedimentary organic matter as a food source for deposit feeders. In: Lopez G, Tagon G, Levinton J (eds) The ecology of marine deposit feeders. Springer Verlag, Berlin, $p$ 98-113

McArdle S, McLachlan A (1991) Dynamics of the swash zone and effluent line on sandy beaches. Mar Ecol Prog Ser 76: 91-99

Editorial responsibility: Otto Kinne (Editor-in-Chief), Oldendorf/Luhe, Germany
McArdle S, McLachlan A (1992) Sand beach ecology: swash features relevant to the macrofauna. J Coast Res 8: 398-407

McLachlan A (1980) The definition of sandy beaches in relation to exposure: a simple rating system. S Afr J Sci 76:137-138

McLachlan A (1990) Dissipative beaches and macrofauna communities on exposed intertidal sands. J Coast Res 6:57-71

McLachlan A, Dorvlo A (2005) Global patterns in sandy beach macrobenthic communities. J Coast Res 21:674-687

McLachlan A, Jaramillo E, Donn TE, Wessels F (1993) Sandy beach macrofauna communities and their control by the physical environment: a geographical comparison. J Coast Res 15:27-38

McLachlan A, Jaramillo E, Defeo O, Dugan J, de Ruyck A, Coetzee P (1995) Adaptations of bivalves to different beach types. J Exp Mar Biol Ecol 187:147-160

Noy-Meir I (1979) Structure and function of desert ecosystems. Isr J Bot 28: 1-19

Palacio J, Lastra M, Mora J (2001) Distribución vertical de la macroinfauna intermareal en la ensenada de Lourizán (Ría de Pontevedra). Thalassas 9:49-62

Pfannkuche O (1993) Benthic response to sedimentation of particulate matter at the BIOTRANS station, $47^{\circ} \mathrm{N}, 20^{\circ} \mathrm{W}$. Deep-Sea Res 40:135-149

Rodríguez JG, Lastra M, López J (2003) Meiofauna distribution along a gradient of sandy beaches in northern Spain. Estuar Coast Shelf Sci 58:63-69

Salvat B (1964) Les conditions hydrodynamiques instertitielles des sédiments meubles intertidaux et la répartition verticale de la faune endogée. CR Acad Sci Paris 259: 1576-1579

Schoeman DS, Richardson AJ (2002) Investigating biotic and abiotic factors affecting the recruitment of an intertidal clam on an exposed sandy beach using a generalized additive model. J Exp Mar Biol Ecol 276:67-81

Short AD (1999) Handbook of beach and shoreface morphodynamics. John Wiley \& Sons, New York

Sokal RR, Rohlf FJ (1995) Biometry: the principles and practice of statistics in biological research, $3^{\text {rd }}$ edn. WH Freeman, New York

Stanley SM (1970) Relation of shell form to life habitats of the bivalvia (Mollusca). Geol Soc Am Mem 125:1-296

Talbot MMB, Bate GC (1989) Beach morphodynamics and surfzone diatom populations. J Exp Mar Biol Ecol 129:231-241

Trevor JH (1976) The burrowing activity of Nephtys cirrosa Ehlers (Annelida: Polychaeta). J Exp Mar Biol Ecol 24: 307-319

Trueman ER, Brand AR, Dawis P (1966) The effect of substrata and shell shape on the burrowing of some common bivalves. Malacol Soc Lond Proc 37:97-109

Zöllner N, Kirsch K (1962) Über die quantitative Bestimmung von Lipoiden (Mikromethode) mittels der vielen natürlichen Lipoiden (allen bekannten Plasmolipoiden) gemeinsamen Sulfophosphovanillin-Reaktion. Z Ges Exp Medizin 135:545-561

Submitted: July 13, 2005; Accepted: December 22, 2005

Proofs received from author(s): April 19, 2006 